\title{
GENERATION X VERSUS MILLENNIALS COMMUNICATION BEHAVIOUR ON SOCIAL MEDIA WHEN PURCHASING FOOD VERSUS TOURIST SERVICES
}

\author{
Dan-Cristian Dabija, Brîndușa Mariana Bejan, Nicoleta Tipi
}

\section{Introduction}

The success of 21 st century retailers depends increasingly on their online presence and the development of interesting and attractive communication and presentation of offers to internauts who spend a lot of time on social media interacting with people, catching up on the latest news, commenting on various events and situations and sharing other people's posts (Young, 2015; Dabija et al., 2018). Unlike mature people (Generation $\mathrm{X}$ ) with greater life experience and family responsibilities, who tend to seek high-quality products and services, comparing them and trying to get as much information as possible about future purchases, Millennials or Generation $Y$ give more credence to online comments and posts, often sharing the contents when they like the title, without checking the information in advance (Valentine \& Powers, 2013; Schiopu et al., 2016; Haydam et al., 2017). Gen Xers tend to be more responsible in their use of social media communication, mostly because they became acquainted with mobile devices, modern communication technology and social media during adulthood (Dabija \& Grant, 2016). Millennials exhibit default behaviour when it comes to social media, as modern communication technology is a constant in their lives, a main tool whereby they assess reality and anything they do.

As companies come to understand such behaviour and social trends, they are increasingly faced with the need to define and pursue a social media-based communication strategy by creating Facebook, LinkedIn, Twitter etc. pages, blogs and forums, and fostering the emergence of strong online communities whose exchange of ideas and information helps to improve products and develop new ones
(Bolton et al., 2013; Euromonitor, 2015; Wagner et al., 2016). The focus on younger generations of consumers is a strategy that is all the more justified as, by approaching this segment, companies seek to build or develop a lasting relationship with them. Even if Millennials do not yet have significant financial resources, depending mostly on their parents and grandparents for material support, as they become employed and their income increases, they will purchase and recommend the brands of companies to other people, based on their previous positive experience with them (Dabija et al., 2016; Șchiopu et al., 2016).

An empirical study was conducted by the authors to determine the extent to which social media communication influences Gen Xers' and Millennials' preference for food products versus tourist services. This is down to the information found in social media, the desire to be informed about products and other people's experience of them, the availability of information on social media and the relevant aspects that any piece of information should possess. The study was conducted in Romania over a period of five months in 2016, using a questionnaire as a statistical tool. The results obtained show that, when choosing either food products or tourist services, individuals gave either more or less credence, depending on generation, to comments, recommendations and suggestions from third parties, and sought further information in order to make the best purchasing decision. Following a literature review on Gen Xers' and Millennials' characteristics and consumption behaviour, the authors explain the research methodology and interpretation of results. The paper ends with conclusions and managerial implications, pointing out the research limitations and future directions. 


\section{Millennials and Social Media Communication}

Millennials are the segments companies prefer to approach with their marketing strategy, especially since their number worldwide is very large, and both their purchasing power (Viswanathan \& Jain, 2013; Loroz \& Helgeson, 2013; Young, 2015; Haydam et al., 2017) and capacity to influence other people to buy products increases (Euromonitor, 2015). Globally, it is estimated that Millennials' annual purchasing power is over $\$ 170$ billion (Cheung et al., 2008; Loroz \& Helgeson, 2013; Young, 2015). Their buying behaviour, lifestyle and consumption patterns differ greatly from those of their predecessors (Eastman \& Liu, 2012; Gurău, 2012; Șchiopu et al., 2016; Dabija et al., 2017), while their penchant for online technologies, portable devices, social media, etc., entices companies into studying them and developing effective communication campaigns and customized offers (Bellman et al., 2009; Viswanatha \& Jain, 2013; Elite Daily, 2015).

Millennials have unique characteristics that arouse the interest of marketers. For instance, they are highly tolerant, pay increased attention to social responsibility campaigns, take part in humanitarian actions and have a strong desire to do more and more travelling and attend various events and festivals (Valentine \& Powers, 2013). Millennials place great trust in marketed products and pay much attention to the promotion campaigns of companies (Cone Inc., 2006). Indeed, companies have made substantial changes to their communication strategies, because nowadays Millennials can no longer be "targeted" solely via traditional media (Valentine \& Powers, 2013), social media and online campaigns having increasingly caught their attention (Dabija \& Grant, 2016; Șchiopu et al., 2016).

Millennials or Echo Boomers are an important segment for retailers because their entry into the labour market allows them to have their own income and increase their spending, which is usually reflected in their consumption of products and services. Millennials exhibit "powerful aggregate spending habits" (Cui et al., 2003; Krotz, 2005), as they are keen on food, tourist services and services helping them to maintain or improve their health (Barbagallo, 2003; Epuran et al., 2017). Another contributing factor is the fact that Millennials view shopping as a form of relaxation, which has helped many food and non-food retailers to expand their businesses (Bakewell \& Mitchell, 2003). In other words, Millennials represent the retailers' favourite target group (Pamfilie et al., 2016; Dabija et al., 2017). Millennials have, over time, stood out as the "high-tech" generation, their penchant for technology and acquaintance with various devices and gadgets being one of the main elements that differentiates them from other generations. Therefore, for marketers, they are people with relevant purchasing power (Eastman \& Liu, 2012; Dabija \& Grant, 2016; Șchiopu et al., 2016; Haydam et al., 2017).

However, it is the large amount of time that Millennials spend online that gives companies "a rough ride", because they have to identify the best means, ways and strategies to reach Millennials by means of effective advertising campaigns (Hershatter \& Epstein, 2010; Valentine \& Powers, 2013; Young, 2015). Traditional advertising does not have the same effect on Millennials as on previous generations (Valentine \& Powers, 2013; Young, 2015) because of their reluctance to use anything that is "not digital", and the fact that the online environment is more trustworthy and provides them with greater information safety (Neuborne, 1999; Valentine \& Powers, 2013; Young, 2015). Millennials prefer advertising spots and clips broadcast on YouTube and other video channels, the in-game advertising and the popup ads on the accessed web pages (Taken Smith, 2011; Young, 2015).

Social networks and the online environment are essential elements in the lives of Millennials (Eastman \& Liu, 2012). Millennials are "objectively motivated shoppers" (Martin \& Turley, 2004) who pay attention to store environmental variables and retailers' technological incentives in their decisionmaking and purchasing process. The Internet represents their main source of information, its usage being reflected in the large number of social networking websites on which they have accounts and frequently interact with other people. After the Internet, television seems to be the second favourite channel for gaining information, recent studies showing that Millennials spend more time in front of their TV sets than Gen Xers or Baby Boomers (Strategic Direction, 2015). As a result, retailers have been compelled to revise their communication strategy intended for Millennials. Millennials are often impervious to traditional advertising, 
paying it scant attention (Strategic Direction, 2015). This is reflected in their lack of interest in products advertised through such channels. The emergence of social networks has enabled companies to build brand affinity with their customers. Internet users can "track" the entry and evolution of a product on the market, access the comments of other people and help them develop an interest in the product. Interest in a product expressed through social networks has led to the emergence of "virtual communities" which bring together consumers interested in, or who have developed a passion for certain company products (Bolton et al., 2013).

Millennials are greatly influenced by wordof-mouth (WOM) recommendations (Strategic Direction, 2015). The recommendations from friends and acquaintances, as well as the opinions and dissatisfaction expressed on social networks, forums, blogs etc., are very important to them. Millennials prefer these communication channels, mostly due to the swift information sharing which allows the exploration of new and unknown things and enables them to meet with new people (Mengü et al., 2015). Social networks have brought about a shift in individuals' behaviour, preferences, values, identity, expectations about product performance and satisfaction with a product or service, which often evolves from an intangible and abstract process to a unique, dynamic and fun experience. Therefore, their commitment to companies can be influenced much more easily through social media (Bolton et al., 2013).

The final purchasing decision is often influenced by online comments and recommendations which Millennials find more credible than the information provided by companies themselves (Dabija et al., 2017). As retailers become more aware of and understand this reality, in their attempt to draw Millennials, they focus on influencing young Millennials reference groups, that is, the individuals able to trigger a favourable response from Generation Y members (Strategic Direction, 2015). Unlike consumers who are easily approached via classical means of media communication, in the case of Millennials, companies have switched from traditional channels to virtual channels, changing the contents of the message conveyed along the way (Dabija \& Grant, 2016; Haydam et al., 2017; Dabija et al., 2018). Greater emphasis is placed at present on the objective presentation of a product or service, but tailored to the preferences, attitudes and behaviour of Millennials.

In comparison with previous generations, Millennials have highly heterogeneous customs and preferences, and varied attitudes and concerns. While people born in the first age range of the Millennial cohort are concerned with career development, the identification of relevant information and establishment of business contacts via social networks, those born in the second age range focus mostly on diversifying the forms of entertainment since, to them, social networks are a means of leisure, communication, socializing and getting informed (Bolton et al., 2013). With knowledge of this reality, companies find it easier to successfully approach target groups in the online environment. Certainly, a company's online activity should be a part of its strategy, while the ongoing improvement of its official pages in social networks, together with their search engine optimization enables the creation of a strong company image amongst users of social media (Duffett, 2015).

\section{Generation $X$ and the Online Communication Strategy}

The members of Generation X are relatively independent persons who grew up in a world in which peace prevailed, unlike their parents, Baby Boomers, who suffered from the effects of conflicts and economic reconstruction. Family, friends or school are their dominant values, which makes them more pragmatic and flexible in their behaviour, more cautious and sceptical of anything new. They refuse to amass material wealth, preferring more spiritual values and pursuing opportunities for intellectual development (Glass, 2007; Hernaus \& Pološki Vokic, 2014; Dabija et al., 2016). This generation is marked by greater cultural and social differences in emerging countries than in developed countries, often encountering adverse circumstances and being affected by poverty and pauperism (Gurău, 2012). In Eastern Europe, Gen Xers were eyewitnesses to the fall of Communism, which developed in them a more liberal thinking as they grew up. They had limited access to Western culture and values and technological advancement, which was more fully understood and appreciated during their adulthood with the emergence of modern communication technology. 
As Gen Xers can be easily influenced by the opinions of others (Acar, 2014), they are more easily targetted by marketers through advertisements. Numerous studies (Littrell et al., 2005; Jackson et al., 2011) have shown that Generation X members have a high level of education and, as a result, are a lot more pragmatic and sceptical. Their fondness for shopping is small, probably because of the effects of the recent global economic recession (Eastman \& Liu, 2012). Realism is one characteristic of Gen Xers, who are accustomed to taking responsibility. Health and financial security represent two major objectives with which Gen Xers are concerned on a daily basis. Although not as familiar with the Internet and new technologies as Millennials, Gen Xers often do online shopping, sometimes as a means of relaxation. Their exposure to online advertising does not exert a major effect on their purchasing decisions, because they have little interest in this type of advertising, which they frequently ignore (Mintel, 2016).

Gen Xers do not harbour a strong dislike of the Internet and the online environment, because they frequently use these sources of information to expand their knowledge (Mitsis \& Foley, 2012). They make their decisions based on recommendations on blogs, forums or social networks and are less influenced by word-ofmouth recommendations. Depending on the type of products and/or services they purchase, Gen Xers are identified by companies along with the Millennials and targetted with similar promotional messages. Recommendations and posts on social networks or e-WOM exert a greater impact on consumers (Susarla et al., 2016), online communication channels being strong "influencers" since they have the ability to draw consumers' attention (Berger \& Schwartz, 2011).

With the development of technology and social networks, word-of-mouth not only applies to recommendations from friends and acquaintances, but also includes social networking websites, allowing users to post comments and recommendations, provide valuable feedback about positive or negative experiences of the purchased products or services and also forge friendships with people all over the world. Word-of-mouth or social communication is the primary factor behind $20-50 \%$ of all purchasing decisions. It is a credible source of information for both generations of consumers, because it also involves sharing the personal experience of an individual who states his or her opinion about a product or service (Chawdhary \& Dall Olmo Riley, 2015).

Immateriality and heterogeneity are two characteristics that make social communication even more important for a consumer considering "purchasing" a service. Due to the risk incurred when purchasing, an individual need further evidence that the service performance meets his or her expectations. Recommendations on social networks may increase customer trust, because the individual can make the best decision having gained knowledge from his or her fellow consumers about as many similar actual experiences as possible. The objectivity of such opinions is all the more important, as companies have less control over them in comparison with the control exerted, for instance, by promotional spots (Chawdhary \& Dall OImo Riley, 2015). The effect of e-WOM on businesses is significant due to the high speed of information dissemination in the online environment. It also enables consumers to spread negative opinions with greater frequency. Since consumers pay greater attention to the opinions shared by other people than to company advertisements, a negative e-WOM may affect a company's reputation (Zhang et al., 2017). Unlike Millennials, Gen Xers are not so accustomed to the new technologies and devices designed by companies, as these are not usually an integral part of their life. This may affect either the credence they lend to the information available on social networks or the actual usage of such devices.

\section{Research Methodology \\ 3.1 Sample Structure}

The research was conducted on a sample of 755 people of whom $54.6 \%$ were females and $45.4 \%$ were males. Data was collected during Spring 2016 in the second largest city of Romania. The sample representativeness for the two generations considered was slightly disproportionate in the case of Millennials because of the way in which data were collected, namely, with the aid of volunteers.

As such studies have not been conducted before in a Romanian context, we relied on random sampling. However, the results can be deemed relevant because the research was empirical and exploratory in nature. Most respondents lived in urban areas $(87.8 \%)$, but there were also a significant number of people, 


\begin{tabular}{|c|c|c|c|c|c|c|}
\hline \multirow{3}{*}{ Characteristic } & \multicolumn{6}{|c|}{ Generations of consumers } \\
\hline & \multicolumn{2}{|c|}{$\begin{array}{c}\text { Millennials }(Y) \\
\text { (aged 18-35) }\end{array}$} & \multicolumn{2}{|c|}{$X$ (aged 36-50) } & \multicolumn{2}{|c|}{ Total } \\
\hline & $\mathbf{n}$ & $\%$ & $\mathbf{n}$ & $\%$ & $\mathbf{n}$ & $\%$ \\
\hline \multicolumn{7}{|l|}{ Gender } \\
\hline Male & 226 & 29.9 & 117 & 15.5 & 343 & 45.4 \\
\hline Female & 285 & 37.7 & 127 & 16.8 & 412 & 54.6 \\
\hline Total & 511 & 67.7 & 244 & 32.3 & 755 & 100.0 \\
\hline \multicolumn{7}{|l|}{ Domicile } \\
\hline Urban & 457 & 60.5 & 206 & 27.3 & 663 & 87.8 \\
\hline Rural & 54 & 7.2 & 38 & 5.0 & 92 & 12.2 \\
\hline Total & 511 & 67.7 & 244 & 32.3 & 755 & 100.0 \\
\hline \multicolumn{7}{|l|}{ Labour market status } \\
\hline Student & 246 & 32.6 & 2 & 0.3 & 248 & 32.8 \\
\hline Employed & 250 & 33.1 & 210 & 27.8 & 460 & 60.9 \\
\hline Unemployed & 15 & 2.0 & 32 & 4.2 & 47 & 6.2 \\
\hline Total & 511 & 67.7 & 244 & 32.3 & 755 & 100.0 \\
\hline \multicolumn{7}{|l|}{ Income } \\
\hline Below the minimum wage $(1,050$ lei) & 107 & 14.2 & 14 & 1.9 & 121 & 16.0 \\
\hline $\begin{array}{l}\text { Between one and two minimum wages } \\
(1,051-2,100 \text { lei) }\end{array}$ & 142 & 18.8 & 70 & 9.3 & 212 & 28.1 \\
\hline $\begin{array}{l}\text { Between two and four minimum wages } \\
(2,101-4,200 \text { lei) }\end{array}$ & 68 & 9.0 & 71 & 9.4 & 139 & 18.4 \\
\hline Over four minimum wages $(4,200$ lei) & 7 & 0.9 & 18 & 2.4 & 25 & 3.3 \\
\hline Total & 511 & 67.7 & 244 & 32.3 & 755 & 100.0 \\
\hline
\end{tabular}

\section{Tab. 2: Results of testing data validity and trustworthiness}

\begin{tabular}{l|c|c|c|c|c|c}
\multicolumn{1}{c|}{ Dimension } & $\begin{array}{c}\text { No. of } \\
\text { items }\end{array}$ & $\mathbf{\alpha}^{\mathbf{1}} \mathbf{>} \mathbf{0 . 7}$ & $\mathbf{K M O}^{2} \mathbf{>} \mathbf{0 . 7}$ & $\mathbf{X}^{\mathbf{2}} ; \mathbf{d f ;} \mathbf{p}^{\mathbf{3}}$ & $\begin{array}{c}\text { Eigen- } \\
\text { value }\end{array}$ & \% variance \\
\hline $\begin{array}{l}\text { Desire to obtain } \\
\text { information (ID) }\end{array}$ & 4 & 0.933 & 0.914 & $3.331 ; 211 ;{ }^{* * * *}$ & 2.743 & 68.134 \\
\hline $\begin{array}{l}\text { Use of the Internet as } \\
\text { source of information (IIS) }\end{array}$ & 3 & 0.842 & 0.854 & $704 ; 112 ;{ }^{* * * *}$ & 2.321 & 69.735 \\
\hline $\begin{array}{l}\text { Characteristics expected } \\
\text { from information (DCI) }\end{array}$ & 5 & 0.921 & 0.921 & $1.321 ; 211 ;{ }^{* * * *}$ & 2.544 & 61.113 \\
\hline $\begin{array}{l}\text { Communicating via social } \\
\text { media (CSM) }\end{array}$ & 5 & 0.897 & 0.902 & $1.267 ; 230 ;{ }^{* * * *}$ & 2.438 & 60.345 \\
\hline
\end{tabular}

Note: ${ }^{1}$ - Cronbach a coefficient (check of data trustworthiness); ${ }^{2}$ - Kaiser-Meyer-Ohlin criterion (exploratory factor analysis) for each dimension; ${ }^{3}-$ Bartlett's sphericity test $\left(x^{2}-\right.$ chi square, $d f-$ degrees of freedom, $p-$ probability; ${ }^{* * * *} p<0.001 ;{ }^{* * *} p<0.01 ;{ }^{* *} p<0.05 ;{ }^{*} p<0.1$ ) 
particularly among Millennials, living in rural areas. For the most part, the interviewees were employed $(60.9 \%)$ and there was relative similarity between the two generations in this regard (33.1\% Millennials versus $27.8 \%$ adult persons were employed) (Tab. 1).

The respondents' income varied between the two generations. Approximately $60 \%$ of adults earned between one and four minimum wages per month, while $50 \%$ of Millennials earned up to two monthly net minimum wages. In fact, as experience increased, so did respondents' wages (Tab. 1).

\subsection{Data Validity and Reliability}

Following the data collection, statistical tests were performed using Cronbach's $\alpha$ coefficient $(\alpha>0.7)$, the KMO criterion (>0.7) and Bartlett's sphericity test in SPSS (Tab. 2). The factors used to characterize each dimension have been included in an exploratory factor analysis in SPSS. This has been considered with the aim of establishing their stability (Eigen value $>1$ and $\%$ variance $>50 \%$ ). Also, the values obtained for these dimensions, for the $X^{2}$ and df indicate that they could be clearly delimitated from the point of view of respondents. Since the considered dimensions meet the minimum acceptable threshold levels, the results were interpreted using structural equation modelling in AMOS (Churchill, 1991).

\section{Results and Discussion}

The results were validated in compliance with the objective of the research to determine the extent to which social media communication influences Gen Xers' and Millennials' preference for food products versus tourist services as a result of the information found in social media, their desire to be informed about the characteristics of products and other people's experience of them, the availability of information on social media and the relevant aspects that any piece of information should possess. The research was conducted on two key purchases (food and tourism services), as these were familiar to all using online services. Therefore, the model presented in Fig. 1 has been analyzed with respect to all three factors that determine the extent to which the Millennials and the adult generation (Gen Xers) used communication and information gained through social media. This was to add content about food products and tourist services based on respondents' desire to be informed, the extent to which they used the Internet as the main source of information about food and tourist services, together with the characteristics expected from an item of information to elicit a reaction from people. The analyses were conducted separately for each of the two generations as well as for each of the two products (food and tourist products).

\section{Fig. 1: The investigated general model}

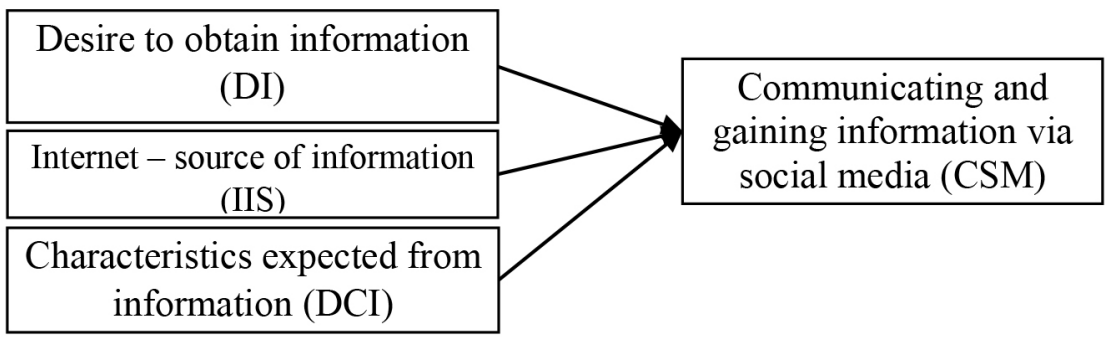




\subsection{The General Model - All Respondents}

As can be seen in Tab. 3, the model in Fig. 1 could be validated because the model fit indices exceed the minimum threshold levels (>0.8; $\leq 0.08$ ), in accordance with the values specified in the literature (Forza \& Filippini, 1998; Ju et al., 2006). The model is stable so that the next stage was the interpretation of results.

The respondents' use of social media to communicate information about food and tourist services was determined to a great extent by the Internet as the source of information for finding out about the latest product characteristics, and viewing comments of other users and recommendations made by other internauts. These aspects are also confirmed by the literature (Bounie et al., 2008; Godes et al., 2005; Young, 2015). The influence and significance $\left(0.565^{\star * * *}\right)$ of this component was very great because it exerted a strong impact on Millennials' behaviour with regards to the communication of product and service characteristics via social media.

A secondary role in terms of influence, intensity of connection and significance was played by respondents' desire to obtain information, regardless of generation $\left(0.150^{* * *}\right)$. This showed that it was important for them to keep up to date with the latest news, be properly informed and make the best decisions based on the available data. The smallest influence and lowest impact on the communication of opinions about various types of products via social media was recorded for characteristics of information $\left(0.030^{*}\right)$. It is very likely that respondents were not much concerned about the obtained information, as it was more important for them to "know" and keep abreast of the latest news. As the literature shows (Dabija et al., 2017),
Millennials' "thirst" for knowledge, targeting any kind of information, which they immediately access and view as relevant and up-to-date.

\subsection{The General Model - Generations Compared}

The model breakdown by the two generations could also be validated because the fit indices exceeded the minimum acceptable threshold levels $(>0.8 ; \leq 0.08)$. The results show some interesting peculiarities. For Millennials or Generation $Y$ members (aged between 19 and 34), a significant impact was exerted by the Internet as a general source of information $\left(0.397^{\star * * *}\right)$, as the information obtained from the Internet was used to further communicate the characteristics of food products and tourist services via social media. Millennials' desire to be informed did not have a significant influence, although a certain impact was recorded $\left(0.123^{\text {n.s. }}\right)$. They seemed to be more concerned with the characteristics expected from information, and analyzed these very carefully $\left(0.135^{*}\right)$.

This may be accounted for by the fact that Millennials actually grew up with the Internet, probably being as important to them as the consumption of food or sleeping. Gaining information is, to them, a "default" characteristic, a constant day-to-day activity, a feature of their own existence, and not something unusual or atypical. To them, being informed is a "takenfor-granted" aspect of life. When communicating via social media, Millennials actually filter out non-relevant information and only retain and post what they deem relevant and worth seeing by other people (Tab. 4). In comparison with Gen Xers, the members of this generation seemed to exhibit better judgement concerning information posted online, especially the product characteristics communicated via social media.

Tab. 3: Factors determining the use of social media for communication

\begin{tabular}{|c|c|c|c|c|}
\hline All generations & 755 respondents & $x^{2}$ & $X^{2} / d f$ & GFI \\
\hline ID $\rightarrow$ CSM & $0.150^{* * *}$ & 682.711 & 5.133 & 0.948 \\
\hline IIS $\rightarrow$ CSM & $0.565^{\star \star \star *}$ & RMSEA $(\leq 0.08)$ & TLI & AGFI \\
\hline $\mathrm{DCl} \rightarrow \mathrm{CSM}$ & $0.030^{*}$ & 0.075 & 0.908 & 0.926 \\
\hline n.s. - insignificant & ${ }^{* *} p<0.05$ & $\operatorname{SRMR}(\leq 0.08)$ & $\mathrm{NFI}$ & $\mathrm{CFI}$ \\
\hline${ }^{* * *} p<0.01$ & $* * * * p<0.001$ & 0.0598 & 0.903 & 0.911 \\
\hline
\end{tabular}


Tab. 4: Factors determining the use of social media for communication, broken down by generations

\begin{tabular}{|c|c|c|c|c|}
\hline \multicolumn{2}{|c|}{ Millennials (Generation $Y$ ) $=511$ persons } & \multirow{2}{*}{$\begin{array}{c}x^{2} \\
1,046.435\end{array}$} & \multirow{2}{*}{$\begin{array}{c}\mathrm{df} \\
365\end{array}$} & \multirow{2}{*}{$\begin{array}{l}x^{2} / d f \\
2.8665\end{array}$} \\
\hline & $0.123^{\text {n.s. }}$ & & & \\
\hline & $0.397^{* * * *}$ & \multicolumn{2}{|c|}{ RMSEA $(\leq 0.08)$} & GFI \\
\hline & $0.135^{*}$ & \multicolumn{2}{|c|}{0.047} & 0.971 \\
\hline \multicolumn{2}{|c|}{ Generation $X=244$ persons } & \multirow{2}{*}{\multicolumn{2}{|c|}{$\begin{array}{c}\text { SRMR }(\leq 0.08) \\
0.08\end{array}$}} & $\mathrm{NFI}$ \\
\hline & $0.204^{*}$ & & & 0.903 \\
\hline & $0.510^{* * * *}$ & TLI & AGFI & $\mathrm{CFI}$ \\
\hline & $-0.015^{\text {n.s. }}$ & 0.944 & 0.938 & 0.961 \\
\hline${ }^{*} p<0.1$ & $* * * * p<0.001$ & \multicolumn{3}{|c|}{ n.s. - insignificant } \\
\hline
\end{tabular}

Source: own research

In the case of Gen Xers, the communication of various product characteristics via social media was overwhelmingly determined by the Internet as the primary source of information for this target group $\left(0.510^{\star * * *}\right)$ and by their desire to gain information $\left(0.204^{*}\right)$. The Internet played a major role in mediating the relationship with the information conveyed by these Millennials via social media, while their desire to be informed played a secondary role, being less intensive and having a smaller level of significance. The "characteristics expected from information" did not exert a significant impact for this generation $\left(-0.015^{\text {n.s. }}\right)$, probably because they believed the experience gained was sufficient and complemented the information obtained online and from other sources (Tab. 5).

\subsection{Model Breakdown by Generations and Types of Products and Services}

The breakdown of the model in Fig. 1 by food products and tourist services and its analysis for the whole number of respondents (Tabs. 5 and 7 ), as well as for each generation $Y$ and $X$ (Tabs. 6 and 8) revealed some peculiarities. As can be seen, the fit indices of each model falls within the minimum acceptable threshold levels $(>0.8 ; \leq 0.08)$. This confirms the model fit is correct (Forza \& Filippini, 1998; Ju et al., 2006), which allows the validation of the models and the realization of proper interpretations.

\section{Food products}

The online information $\left(0.550^{\star * * *}\right)$ made a major contribution in communicating product characteristics via social media. Respondents' desire to always be informed $\left(0.144^{* *}\right)$ had a lower influence. The factor "characteristics expected from information" did not have a significant impact $\left(0.046^{\text {n.s. }}\right)$. We believe that, in so far as respondents obtained favourable reviews of food products and had the desire to find out more information, they enriched the existing social media content about

Tab. 5: Factors determining the use of social media for food products

\begin{tabular}{|c|c|c|c|c|c|}
\hline \multicolumn{2}{|c|}{ Foodstuff } & \multirow{2}{*}{$\begin{array}{c}x^{2} \\
1,052.96\end{array}$} & \multirow{2}{*}{$\begin{array}{c}\text { df } \\
182\end{array}$} & \multirow{2}{*}{$\begin{array}{l}\mathrm{X}^{2} / \mathrm{df} \\
5.78\end{array}$} & \multirow{2}{*}{$\begin{array}{l}\text { AGFI } \\
0.862\end{array}$} \\
\hline ID $\rightarrow$ CSM & $0.144^{* *}$ & & & & \\
\hline IIS $\rightarrow$ CSM & $0.550^{\star \star \star \star}$ & \multicolumn{2}{|c|}{ RMSEA $(\leq 0.08)$} & NFI & TLI \\
\hline $\mathrm{DCl} \rightarrow \mathrm{CSM}$ & $0.046^{\text {n.s. }}$ & \multicolumn{2}{|c|}{0.075} & 0.835 & 0.837 \\
\hline${ }^{* * * *} p<0.001$ & ${ }^{*} p<0.1$ & \multicolumn{2}{|c|}{ SRMR $(\leq 0.08)$} & $\mathrm{CFI}$ & GFI \\
\hline${ }^{* * *} p<0.01$ & ${ }^{* *} p<0.05$ & \multicolumn{2}{|c|}{0.0655} & 0.859 & 0.891 \\
\hline n.s. - insignifice & & & & & \\
\hline
\end{tabular}


products and their characteristics by sending the information to other consumers and offering recommendations based on their own consumption experience (Tab. 5). Members of Generation X did not pay enough attention to healthy food, preferring fast-food products (Jin et al., 2015).

The same analysis conducted for the two generations of consumers reveals some important differences (Tab. 6). The Internet represented an important source of information for Millennials (aged between 20 and 34) but its influence decreased in intensity in the case of Gen Xers $\left(0.384^{* * * *}\right)$. These results indicate that the younger the consumers, the greater the share of information collected online which they later communicate via social media. A proper understanding of this situation could help companies to develop effective strategies whereby internauts may be "bombarded" with information about the offered products and services. In this way companies may "hope" to increase their online visits and sales, as well the number of recommendations of their products. A greater number of site visits is beneficial, at least for the awareness of the company's own products.

The Millennials' desire to obtain information did not have a significant and relevant $\left(0.119^{\text {n.s. }}\right)$ influence on communicating and gaining information via social media. This may be accounted for by the fact that they took communication for granted as a natural aspect of daily life. The Millennials were constantly in search of new information, but were not actually aware that they had this need. Gen Xers admitted that they had a greater desire to be informed and, as such, the impact of this dimension on communication via social media is relatively substantial and somewhat significant $\left(0.201^{*}\right)$. The same holds true for the characteristics expected from information. This factor did not have a significant impact on Millennials' communication via social media $\left(0.147^{\text {n.s. }}\right)$. For Gen Xers, the characteristics of information played a slightly significant role, albeit one of low intensity $\left(0.108^{*}\right)$ in communicating and gaining information via social media. Due to their life experience, knowledge and tough situations they may have faced in the past, elderly people are likely to be more careful about what they communicate and convey to other people. They are more cautious than Millennials when posting content about products in the social media on which they are active (Tab. 6).

This apparent paradox gives rise to the question of to what extent Millennials are especially curious about the credibility of online information. The results seem to indicate that they are "gross" and especially credulous consumers of information. The decisions they make - for instance, regarding the recommendation of various product characteristics to other people - are not based on previously verified information, but the information is further sent in the form of comments, posts, likes and shares, and so on. It may also be that even if they have not "tasted" a particular product, they quickly send further information without attempting to understand if the information is really true or accurate. Knowledge of this reality represents real business opportunities for companies, and retailers could obtain favourable and rapid answers from consumers.

\begin{tabular}{|c|c|c|c|c|c|c|}
\hline Tab. 6: & $\begin{array}{l}\text { Fact } \\
\text { med }\end{array}$ & $\begin{array}{l}\text { mining comn } \\
\text { :ase of food }\end{array}$ & $\begin{array}{l}\text { unication an } \\
\text { oducts, bro }\end{array}$ & $\begin{array}{l}\text { le gair } \\
\text { dowr }\end{array}$ & $\begin{array}{l}f \text { informa } \\
\text { en Xers a }\end{array}$ & $\begin{array}{l}\text { ia social } \\
\text { illennials }\end{array}$ \\
\hline Millennia & (Gen & $=511$ persons & $x^{2}$ & $\mathrm{df}$ & $x^{2} / d f$ & AGFI \\
\hline ID $\rightarrow$ & CSM & $0.119^{\text {n.s. }}$ & $1,641.765$ & 578 & 2.840 & 0.912 \\
\hline IIS $\rightarrow$ & CSM & $0.497^{* \star \star *}$ & RMSEA & $0.08)$ & $\mathrm{NFI}$ & TLI \\
\hline $\mathrm{DCl}-$ & CSM & $0.147^{\text {n.s. }}$ & & & 0.85 & 0.905 \\
\hline & eratio & persons & SRMR & $.08)$ & $\mathrm{CFI}$ & GFI \\
\hline ID $\rightarrow$ & CSM & $0.201^{*}$ & & & 0.921 & 0.943 \\
\hline IIS $\rightarrow$ & CSM & $0.384^{* * * *}$ & ${ }^{* * * *} p<0.001$ & ${ }^{*} p<0.1$ & ${ }^{* * *} p<0.01$ & ${ }^{* *} p<0.05$ \\
\hline $\mathrm{DCl}-$ & CSM & $0.108^{*}$ & n.s. - ins & icant & & \\
\hline
\end{tabular}




\begin{tabular}{|c|c|c|c|c|}
\hline $\begin{array}{ll}\text { b. 7: } & \text { Factc } \\
\text { abou }\end{array}$ & \multicolumn{4}{|c|}{$\begin{array}{l}\text { Factors determining communication and the gaining of information } \\
\text { about package tours }\end{array}$} \\
\hline \multicolumn{2}{|c|}{ Tourist products } & df & $x^{2} / d f$ & AGFI \\
\hline $\mathrm{ID} \rightarrow \mathrm{CSM}$ & $0.152^{* * *}$ & 987.67 & 5.42 & 0.867 \\
\hline IIS $\rightarrow$ CSM & $0.543^{* * * *}$ & $\operatorname{RMSEA}(\leq 0.08)$ & NFI & TLI \\
\hline $\mathrm{DCl} \rightarrow \mathrm{CSM}$ & $0.046^{\text {n.s. }}$ & 0.072 & 0.847 & 0.852 \\
\hline${ }^{* * * *} p<0.001$ & ${ }^{*} p<0.1$ & $\operatorname{SRMR}(\leq 0.08)$ & CFI & GFI \\
\hline${ }^{* * *} p<0.01$ & ${ }^{* *} p<0.05$ & 0.068 & 0.871 & 0.895 \\
\hline \multicolumn{2}{|c|}{ n.s. - insignificant } & & & \\
\hline
\end{tabular}

\section{Tourist products}

The behaviour towards tourist products was extremely varied. The factors with the greatest contribution to the communication and gaining of information via social media were the Internet as a general source of information $\left(0.543^{\star * * *}\right)$ and respondents' desire to be informed about the latest tourist news and offers of package tours $\left(0.152^{* * *}\right)$. In fact, respondents were interested in learning the opinions of their generation peers who had enjoyed the services of a lodging unit or a tour operator, or who had visited a tourist destination and were favourably impressed (Tab. 7).

The breakdown of results by generation (Tab. 8) indicates a strong influence of the Internet as a source of information on the communication of content via social media. The intensity of this dimension was greater with adult people $\left(0.420^{* * * *}\right)$ and weaker with Millennials $\left(0.395^{\star * * *}\right)$, but strongly significant in both cases. The results support the statement that adult people seek to be better informed about tourist products. When sending online content and making posts, they relied on online recommendations and available data, as well as other sources of information to identify the destination of their next vacation and choose the best lodging unit and most comfortable means of transportation. The impact of Millennials' desire to be informed on the communication of content via social media had low intensity and significance $\left(0.123^{*}\right)$ but was slightly more intense with Gen Xers $\left(0.221^{* *}\right)$. While vacations and holidays might not be particularly relevant to the lifestyle of Millennials, the situation changed as people started work, because they increasingly felt the need to be informed about the best resorts to choose and spend their vacations, with the objective of enjoying both comfort and quality. This explains why Gen Xers' desire to be informed about the selection of the best possible vacation destinations was more intense and significant than that of Millennials. The characteristics expected from information

Tab. 8: Factors determining communication and the gaining of information via social media in the case of tourist products, broken down by Gen Xers and Millennials

\begin{tabular}{|c|c|c|c|c|c|}
\hline \multicolumn{2}{|c|}{ Millennials (Generation $Y$ ) $=511$ persons } & \multirow{2}{*}{$\begin{array}{c}x^{2} \\
1,595.328\end{array}$} & \multirow{2}{*}{$\begin{array}{c}d f \\
578\end{array}$} & \multirow{2}{*}{$\begin{array}{l}\mathrm{X}^{2} / \mathrm{df} \\
2.760\end{array}$} & \multirow{2}{*}{$\begin{array}{l}\text { AGFI } \\
0.816\end{array}$} \\
\hline ID $\rightarrow$ CSM & $0.123^{*}$ & & & & \\
\hline IIS $\rightarrow$ CSM & $0.395^{\star \star \star *}$ & \multicolumn{2}{|c|}{$\operatorname{RMSEA}(\leq 0.08)$} & NFI & TLI \\
\hline $\mathrm{DCl} \rightarrow \mathrm{CSM}$ & $0.148^{\text {n.s. }}$ & \multicolumn{2}{|c|}{0.045} & 0.859 & 0.815 \\
\hline \multicolumn{2}{|c|}{ Generation $X=244$ persons } & \multirow{2}{*}{\multicolumn{2}{|c|}{$\begin{array}{c}\text { SRMR }(\leq 0.08) \\
0.08\end{array}$}} & $\mathrm{CFI}$ & GFI \\
\hline ID $\rightarrow$ CSM & $0.221^{* *}$ & & & 0.830 & 0.846 \\
\hline IIS $\rightarrow$ CSM & $0.420^{* * * *}$ & ${ }^{* * * *} p<0.001$ & ${ }^{*} p<0.1$ & ${ }^{* * *} p<0.01$ & ${ }^{* *} p<0.05$ \\
\hline $\mathrm{DCl} \rightarrow \mathrm{CSM}$ & $-0.140^{\text {n.s. }}$ & \multicolumn{2}{|c|}{ n.s. - insignificant } & & \\
\hline
\end{tabular}


did not exert a strong or significant influence on the level of communication via social media for either of the two generations.

\section{Conclusions}

Social media communication was a decisive factor behind Millennials' and Gen Xers' choice of food products and tourist services. When making purchasing decisions, respondents relied on the online information and comments from other people, as well as on those posted on the official pages of companies. They also based their buying decisions on the characteristics of food products and tourist services, always aiming to keep abreast of the latest usage possibilities and obtaining knowledge of any criticisms or possible flaws. This enquiring behaviour, characterized by the desire to gain further information about food products and tourist services was stronger among Gen Xers than Millennials, which shows that the former paid greater attention to, and were more responsible towards the decision to buy a food product or a service. Millennials expected the online information to be more useful in making a purchasing decision, while adults relied mostly on the objective data obtained from sources as credible as possible.

The knowledge of such realities could enable companies to develop an appropriate strategy, designed to help them draw the attention of Millennials and make them choose certain products or services, depending on the experiences and satisfaction of other people. As a matter of fact, the comments and posts of an unknown person seemed more credible to Millennials than a company's official recommendations. Adults were more concerned with, and more heedful of product characteristics, especially of online information, which hampered retailers' efforts to obtain a fast answer from them. However, Gen Xers' weighing more carefully the online information should make retailers more responsible towards their own products, brands and services, taking immediate measures if any flaws or usage problems are identified. Retailers should always try to innovate and modify the characteristics and performance of products and services so that these may best meet individuals' expectations and preferences. It is possible that the Gen Xers were more difficult to approach for two reasons. First, their higher income entitled them to be more pragmatic in assessing social media comments, and more finicky about choosing products. Second, their life experience increased with their age, making them more cautious with respect to any new purchasing act.

Among the research limitations is the fact that no comparative analysis was conducted on the types of social networks used by respondents. Recent studies (DailyBusiness, 2017) show that Facebook is the most popular social network in Romania, with more than 7 million users, followed by Linkedln with 1.2 million users and Twitter with less than 0.1 million users. While Facebook is mostly used to communicate with friends and for leisure purposes, Linkedln hosts in particular the users' business profiles. Another limit is the fact that the research only concerned food products and tourist services. Future research should naturally attempt to include other types of products, such as fashion articles, electronic and household products, entertainment services, etc. Additionally, any future research might take into account the possibility of conducting analyses on Generation $Z$ as well as older persons belonging to the Baby Boomers generation (Dabija et al., 2017).

This work was supported by a grant of the Romanian National Authority for Scientific Research and Innovation, CNCS-UEFISCDI, project number PN-II-RU-TE-2014-4-0312

\section{References}

Acar, A. B. (2014). Do Intrinsic and Extrinsic Motivation Factors Differ for Generation $X$ and Generation Y? International Journal of Business and Social Science, 5(5), 12-20.

Bakewell, C., \& Mitchell, V. W. (2003). Generation $Y$ female consumer decisionmaking styles. International Journal of Retail \& Distribution Management, 31(2), 95-106. https://doi.org/10.1108/09590550310461994.

Barbagallo, P. (2003). Teens. Target Marketing, 26(4), 65-68.

Bellman, L. T., \& Clark, S. (2009). Fashion Accessory Buying Industry Intentions among Female Millennials. Review of Business, 30(1), 46-57.

Berger, J., \& Schwartz, E. (2011). What Drives Immediate and Ongoing Word of Mouth? Journal of Marketing Research, 48(5), 869-880. https://doi.org/10.1509/jmkr.48.5.869. 
Bolton, R. N., Parasuraman, A., Hoefnagels, A., Kabadayi, S., Gruber, T., Loureiro, Y. K., \& Solent, D. (2013). Understanding Generation $Y$ and their use of Social Media: A Review and Research Agenda. Journal of Service Management, 24(3), 245-267. https://doi. org/10.1108/09564231311326987.

Bounie, D., Bourreau, M., Gensollen, M., \& Waelbroeck, P. (2008). Do Online Customer Reviews Matter? Evidence from the Video Game Industry (Telecom ParisTech Working Paper ESS-08-02). https://doi.org/10.2139/ ssrn.1091449.

Chawdhary, R., \& Dall Olmo Riley, F. (2015). Investigating the consequences of word of mouth from a WOM sender's perspective in the services context. Journal of Marketing Management, 31(9-10), 1018-1039. https://doi. org/10.1080/0267257x.2015.1033443.

Cheung, L., Harker, D., \& Harker, M. (2008). The State of the Art of Advertising from the Consumers' Perspective: A Generational Approach. The Marketing Review, 8(2), 125-146. https://doi.org/10.1362/146934708x314118.

Churchill, G. A. (1991). Marketing Research: Methodological Foundation (5th ed.). Fort Worth: The Dryden Press.

Cone Inc. (2006). The Millennial Generation: Pro-Social and Empowered to Change the World. Boston, MA: Cone, Inc.

Cui, Y., Trent, E. S., Sullivan, P. M., \& Matinu, G. N. (2003). Cause-related marketing: how generation $Y$ responds. International Journal of Retail \& Distribution Management, 31(6/7), 310-321. https://doi. org/10.1108/09590550310476012.

Dabija, D. C., Băbuţ, R., Dinu, V., \& Lugojan, M. (2017). Cross-Generational Analysis of Information Searching based on Social Media in Romania. Transformations in Business \& Economics, 16(2), 248-270.

Dabija, D. C., Băbuţ, R., \& Lugojan, M. I. (2016). Information Search Behaviour Based on Social Media. A Generational Perspective in Romania. In I. Plăiaş, \& R. Ciornea (Eds.), Marketing from Information to Decision. $9^{\text {th }}$ Edition Conference Proceedings (pp. 63-64). Cluj-Napoca: Risoprint.

Dabija, D. C., \& Grant, D. (2016). Investigating Shopping Experience and Fulfillment in Omnichannel Retailing: A Proposed Comparative Study in Romanian and UK of Generation Y Consumers. In D. Menachof (Ed.), Doing the Right Things. Ethical
Issues in Logistics and Supply Chair. Abstracts of the $21^{\text {st }}$ Annual Logistics Research Network Conference (p. 53). Corby, Northamptonshire: The Logistics Institute.

Dabija, D. C., Postelnicu, C., Dinu, V. (2018). Cross-Generational Investigation of Ethics and Sustainability. Insights from Romanian Retailing. In Idowu, S. O., Sitnikov, C., Simion, D., \& Bocean, C. (Eds.), Current Issues in Corporate Social Responsibility. An International Consideration. Cham: Springer International Publishing (pp. 141-163). https://doi.org/10.1007/978-3-319-70449-4_10.

DailyBusiness. (2017). The most popular Social Networks in Romania. Retrieved July 16, 2017, from http://www.dailybusiness.ro/stirinew-media/cele-mai-populare-retele-socialein-romania-97606.

Duffett, R. G. (2015). Facebook advertising's influence on intention-topurchase and purchase amongst Millennials. Internet Research, 25(4), 498-526. https://doi. org/10.1108/intr-01-2014-0020.

Eastman, J. K., \& Liu, J. (2012). The impact of generational cohorts on status consumption: an exploratory look at generational cohort and demographics on status consumption. Journal of Consumer Marketing, 29(2), 93-102. https:// doi.org/10.1108/07363761211206348.

Elite Daily. (2015). Millennial Consumer Trends. Retrieved June 21, 2016, from http://elitedaily.com/news/business/elite-dailymillennial-consumer-survey.

Epuran, G., Tescașiu, B., Todor, R. D., Sasu, K. A., \& Cristache, N., (2017). Responsible Consumption - Source of Competitive Advantages and Solution for Tourist Protection. Amfiteatru Economic, 19(45), 447-462.

Euromonitor. (2015). Millennials Impact of their Behaviour on Global Consumer Markets. Retrieved June 6, 2016, from http://www. euromonitor.com/millennials-impact-of-theirbehaviour-on-global-consumer-markets/report.

Euromonitor. (2009). The World's Gen Xers: Latchkey Kids (29-44s) Come Into Their Own. Retrieved June 7, 2016, from http://www.euromonitor.com/the-worlds-genxers-latchkey-kids-29-44s-come-into-their-own/ report.

Forza, C., \& Filippini, R. (1998). TQM Impact on Quality Conformance and Customer Satisfaction: A Causal Model. International Journal of Production Economics, 55(1), 1-20. https://doi.org/10.1016/s0925-5273(98)00007-3. 
Glass,A. (2007). Understanding Generational Differences for Competitive Success. Industrial and Commercial Training, 39(2), 98-103. https://doi.org/10.1108/00197850710732424.

Godes, D., Mayzlin, D., Chen, Y., Das, S., Dellarocas, C., Pfeiffer, B., Libai, B., Sen, S., Shi, M., \& Verlegh, P. (2005). The Firm's Management of Social Interactions. Marketing Letters, 16(3), 415-428.

Gurău, C. (2012). A life-stage analysis of consumer loyalty profile: comparing Generation $X$ and Millennial consumers. Journal of Consumer Marketing, 29(2), 103-113. https://doi.org/10.1108/07363761211206357.

Haydam, N., Purcarea, T., Edu, T., \& Negricea, I. C. (2017). Explaining Satisfaction at a Foreign Tourism Destination - an IntraGenerational Approach. Evidence within Generation $Y$ from South Africa and Romania. Amfiteatru Economic, 19(45), 528-542.

Hernaus, T., \& Pološki Vokic, N. (2014). Work Design for Different Generational Cohorts. Journal of Organizational Change Management, 27(4), 615-641. https://doi.org/10.1108/jocm-05-2014-0104.

Hershatter, A., \& Epstein, M. (2010). Millennials and the World of Work: An Organization and Management Perspective. Journal of Business Psychology, 25(2), 211-223. https://doi.org/10.1007/s10869-010-9160-y.

Jackson, V., Stoel, L., \& Brantley, A. (2011). Mall attributes and shopping value: differences by gender and generational cohort. Journal of Retailing and Consumer Services, 18(1), 1-9. https://doi.org/10.1016/j. jretconser.2010.08.002.

Jin, N. P., Line, N. D., \& Ann, S. H. (2015). The Full-Service Dining Experience: An Assessment of the Generation-Specific Determinants of Customer Loyalty. Journal of Foodservice Business Research, 18(4), 307-327. https://doi.org/10.1080/15378020.20 15.1068669 .

Ju, T. L., Lin, B., Lin, C., \& Kuo, H. J. (2006). TQM Critical Factors and KM Value Chain Activities. Total Quality Management, 17(3), 373-393. https://doi.org/10.1080/14783360500451614.

Krotz, J. L. (2005). Tough customers: how to reach Gen Y. Redmond, WA: Microsoft Small Business Center.

Littrell, M. A., Ma, Y. J., \& Halepete, J. (2005). Generation X, Baby Boomers, and swing: marketing fair trade apparel. Journal of Fashion
Marketing and Management, 9(4), 407-419. https://doi.org/10.1108/13612020510620786.

Loroz, P., \& Helgeson, J. (2013). Boomers and Their Babies: An Exploratory Study Comparing Psychological Profiles and Advertising Appeal Effectiveness across Two Generations. Journal of Marketing Theory and Practice, 21(3), 289-306. https://doi.org/10.2753/mtp1069-6679210304.

Martin, C., \& Turley, L. (2004). Malls and consumption motivation: an exploratory examination of older Generation $Y$ consumers. International Journal of Retail and Distribution Management, 32(10), 464-475. https://doi.org/10.1108/09590550410558608.

Mengü, S. Ç., Güçdemir, Y., Ertürk, D., \& Canan, S. (2015). Political preferences of generation $Y$ university student with regards to governance and social media: A study on March 2014 local elections. Procedia - Social and Behavioral Sciences, 174, 791-797. https://doi.org/10.1016/j.sbspro.2015.01.616.

Mintel. (2016). Marketing to Generation X - US - June 2016. America: Mintel Group Ltd.

Mitsis, A., \& Foley, P. (2012). Do Generational Membership and Psychographic Characteristics Influence Positive Word of Mouth in a University Context? Asian Academy of Management Journal, 17(1), 1-12.

Neuborne, E., \& Kathleen, K. (1999). Generation Y. Business Week, February 15, 46-50.

Pamfilie, R., Bobe, M., Cristescu, L., \& Toma, M. A. (2016). Innovative Food Quality Models: Developed as an Interface for Modern Consumers and Sustainable Business. Amfiteatru Economic, 18(43), 663-674.

Șchiopu, A. F., Pădurean, A. M., Tală, M. L., \& Nica, A.-M., (2016). The Influence of New Technologies on Tourism Consumption Behavior of the Millennials. Amfiteatru Economic, 18(Special Issue 10), 829-846.

Strategic Direction. (2015). Improving insight on Generation $Y$ consumers: The significance of lifestyle, gender, and media habits. Strategic Direction, 31(4), 22-24. https://doi.org/10.1108/sd-02-2015-0030.

Susarla, A., Oh, J. H., \& Tan, Y. (2016). Influentials, Imitables, or Susceptibles? Virality and Word-of-Mouth Conversations in Online Social Networks. Journal of Management Information Systems, 33(1), 139-170. https://doi.org/10.1080/07421222.2016.11724 54. 


\section{Marketing a obchod}

Taken Smith, K. (2011). Digital Marketing Strategies that Millennials Find Appealing, Motivating, or Just Annoying. Journal of Strategic Marketing, 19(6), 489-499. https://doi. org/10.1080/0965254x.2011.581383.

Valentine, D. B., \& Powers, T. L. (2013). Generation $\mathrm{Y}$ values and lifestyle segments. Journal of Consumer Marketing, 30(7), 597606. https://doi.org/10.1108/jcm-07-2013-0650.

Viswanathan, V., \& Jain, V. (2013). A dual-system approach to understanding "generation $Y$ " decision making. Journal of Consumer Marketing, 30(6), 484-492. https://doi.org/10.1108/jcm-07-2013-0649.

Young, E. (2015). How Millennials Get News: Inside the Habits of America's First Digital Generation. Chicago: Associated PressNORC Center for Public Affairs Research \& American Press Institute.

Zhang, T., Omran, B. A., \& Cobanoglu, C. (2017). Generation Y's positive and negative eWOM: use of social media and mobile technology. International Journal of Contemporary Hospitality Management, 29(2), 732-761. https://doi.org/10.1108/ ijchm-10-2015-0611.
Wagner, U., Reisinger, H., \& Schwand, C. (2016). Fallstudien aus der österreichischen Marketingpraxis 7: Ein Arbeitsbuch zu den Grundzügen des Marketing 7. Vienna: Facultas.

\section{Assoc. Prof. Dan-Cristian Dabija, PhD}

Babeș-Bolyai University Cluj-Napoca Faculty of Economics and Business

Administration

Department of Marketing

Romania

cristian.dabija@econ.ubbcluj.ro

Brîndușa Mariana Bejan

Babeș-Bolyai University Cluj-Napoca Faculty of Economics and Business

Administration

Department of Marketing

Romania

brandusa.bejan@econ.ubbcluj.ro

\author{
Senior Lecturer Nicoleta Tipi, PhD \\ University of Huddersfield \\ The Business School \\ Great Britain \\ n.tipi@hud.ac.uk
}




\title{
Abstract
}

\section{GENERATION X VERSUS MILLENNIALS COMMUNICATION BEHAVIOUR ON SOCIAL MEDIA WHEN PURCHASING FOOD VERSUS TOURIST SERVICES}

\author{
Dan-Cristian Dabija, Brîndușa Mariana Bejan, Nicoleta Tipi
}

Knowledge and proper understanding of the needs, expectations, desires, demands, values or preferences of Generation $X$ and Millennials is an essential goal of any company. The mission of marketers is increasingly difficult because they have to develop a marketing mix able to target efficiently all customers, invoking satisfaction and loyal behavior. Communication strategy therefore has a special role to play. While Millennials are easier to target, persuade even influence through social media, Gen Xers are more conservative, preferring to look for additional information about products and companies themselves, which makes the marketer's job even more difficult. Nowadays, social media plays an increasingly important part in influencing consumers and their consumption behavior. Being able to expand beyond geographical borders, social media creates strong links between consumers in different states and social environments.

Research conducted among Gen Xers and Millennials shows that whenever they choose food products and tourist services based on recommendations and the information available on social media, their purchasing behavior depends on their own personal desire to become informed, and the characteristics they expect from a piece of information and from the Internet as a general source of information. Given this, companies changed and adapted their communication strategies in order to be more present online. In addition, for those interested, companies create official pages that can represent a strong support for those interested in acquiring information. Quite often, consumers have the possibility to compare goods and services before buying, minimizing the risks attached to these acquisitions.

The results reveal that Millennials have stronger affinity with, and place greater reliance upon online information than Gen Xers. From a managerial perspective, this paper provides retailers with the opportunity to better understand the behavior of customers of different ages, making their targeting more successful.

Key Words: Millennials, generation X, social media communication, food, tourist services, information behaviour, purchasing.

JEL Classification: M31, Q01, Q56.

DOI: 10.15240/tul/001/2018-1-013 